\title{
A BRIEF GENEALOGY OF STATE SECRECY
}

\section{Stéphane Lefebvre*}

This article provides a potential explanation to the following question: With over five million government employees and contractors entrusted with state secrets in both Canada and the United States, how could the fact that the vast majority of keepers of state secrets obey the letter of the law be explained? The deterrent effect of the law alone cannot account for this state of affairs. The reason is that subjects self-regulate (psychologically and sociologically speaking) and behave according to contingent forms of rationalities. These forms of rationalities include changing discourses on secrecy and law, and a variety of disciplinary techniques centered on surveillance, hierarchical observation and examination.

Le présent article fournit une réponse explicative possible à la question suivante: Avec plus de cinq millions d'employés et d'entrepreneurs au gouvernement tenus au secret d'État tant au Canada qu'aux États-Unis, comment expliquer que la vaste majorité d'entre-eux respectent la loi à la lettre ? L'effet dissuasif de la loi ne peut, à lui seul, expliquer cet état de choses. L'explication réside dans le fait que les sujets s'autoréglementent (sur les plans psychologiques et sociologiques) et se comportent selon des formes contingentes de rationalisation. Ces formes de rationalisation incluent un changement de discours sur le secret et la loi ainsi que diverses techniques de discipline axées sur la surveillance, le contrôle et le respect hiérarchique.

\section{INTRODUCTION}

In January 2012, the Royal Canadian Mounted Police arrested and charged a Canadian Armed Forces intelligence officer for breach of trust pursuant to Section 122 of the Criminal Code of Canada, and for communicating to a foreign entity information that the Government of Canada was taking measures to safeguard pursuant to Section 16 of the Security of Information Act. In that case, the threat of legal and formal punishment for the unauthorized disclosure of secrets had failed. ${ }^{1}$ With over 150,000 government employees and contractors entrusted with state secrets in Canada, ${ }^{2}$ it is perhaps interesting to note that

PhD candidate, Department of Law \& Legal Studies, Carleton University.

1 For an overview and discussion of Canadian legislative measures and judicial enforcement, see Stanley A Cohen, Privacy, Crime and Terror: Legal Rights and Security in a Time of Peril (Markham, ON: LexisNexis Butterworths, 2005) at 289-352; and Craig Forcese, National Security Law: Canadian Practice in International Perspective (Toronto: Irwin Law, 2008) at 421-433.

2 As of 1 October 2011, 4,863,552 U.S. government employees and contractors were approved for security clearances giving them access to classified information on a need to know basis. US, Office of the Director of National Intelligence, 2011 Report [to Congress] on Security Clearance Determinations (Washington, DC.: Director of National Intelligence, 2012) at 3. There is no exact number available for Canada, but as an indicator, the Canadian Security Intelligence Service received 176,300 requests for security screening from fiscal year 2007-2008 to and including fiscal year 20092010 from government departments and agencies. A secret clearance is valid for 10 years and a top secret clearance for 
few individuals ever betray the trust placed in them by disclosing classified information without authorization. ${ }^{3}$ Even more interesting, I would suggest, would be to attempt to understand better why and how keepers of state secrets continuously obey the law while subjected to societal pressures to increase transparency and witnessing the iniquitous effects of secrecy on democratic accountability and human rights. This fundamentally is a question about the regulation of state secrecy in advanced liberal democratic systems, where state secrecy is, at the very least in principle, the exception and not the rule. ${ }^{4}$

A cogent and detailed explanation accounting for the normal behaviour of keepers of state secrets has yet to be provided by social scientists. Social scientists have consistently neglected the study of secrecy in complex and large organizations and instead paid a significant amount of attention to the study of secrecy in small organizations, such as secret societies and religious sects. ${ }^{5}$ Although there are a few notable exceptions to this general statement (such as the study of secrecy within major religions), social scientists have spent little time theorizing about the "origins, nature, workings, and consequences of secrecy within social systems." 6 As I have alluded, where the study of secrecy has particularly not been neglected is in its breach: "Secrecy is therefore likely to be examined in terms of a deviant form of organizational behavior; it is the illegal and inappropriate use of secrecy that is emphasized." ${ }^{7}$ But what is in need of an explanation are not departures from the norm, but conformity with the norm. Although the threat of punishment is necessary to prevent the unauthorized disclosure of state secrets by secretkeepers, it is supplemented by practices, techniques and forms and rationalities (e.g., discourse, surveillance, examination, material arrangements, etc.) that enable the concealment of information in the

5. Security Intelligence Review Committee, Annual Report 2009-2010 (Ottawa: Public Works and Government Services Canada, 2010) at 30.

3 Frederick Hitz, a former Inspector General of the U.S. Central Intelligence Agency [CIA], lists seven major categories of motivation behind the unauthorized disclosure of classified information, or spying against one's own country:

Ideological commitment; money and treasure; revenge and score settling; sex, intimidation and blackmail; reasons of friendship or ethnic or religious solidarity; and for the sake of the game of spying or doing it. Frederick Hitz, Why Spy?

Espionage in an Age of Uncertainty (New York: Thomas Dunne Books, 2008) at vii. MICE [money, ideology, compromise and ego] is a shorter and popular acronym that encapsulates most cases. Robert W Pringle, Historical Dictionary of Russian and Soviet Intelligence (Lanham, Md: Scarecrow Press, 2006) at 168.

4 The situation is reverse in autocratic systems of government. As Norberto Bobbio writes, "[i]n the autocratic state the state secret is not the exception but the rule: important decisions must be taken away from the prying eyes of the public in any shape or form.” Norberto Bobbio, The Future of Democracy: A Defence of the Rules of the Game, ed, Richard Bellamy, translated by Roger Giffin (Minneapolis: University of Minnesota Press, 1987) at 87.

5 “[...] social science has little interest in the secrecy systems related to the internal politics of complex organizations. Their disregard of the role of information control within such bureaucracies is in marked contrast to their fascination with the secrecy process within small-scale organizations such as secret orders or associations.” Stanton K Tefft, "Secrecy, Disclosure and Social Theory" in Stanton K Tefft, ed, Secrecy: A Cross-Cultural Perspective (New York: Human Sciences Press, 1980) 35 at 60. Patricia Erickson and James Flynn agree with Tefft: "[...] secrecy has rarely received attention within the field of complex organizations. Theoretical perspectives do not include it as a major construct useful for understanding organizational behavior. Research that examines its role in organizational settings is almost non-existent.” Patricia E Erickson \& James Flynn, “Secrecy as an Organizational Control Strategy: Police Planning for a National Political Convention" in Tefft (ibid at 251).

6 Ritchie P Lowry, “Toward a Sociology of Secrecy and Security Systems” in Tefft, ibid 297 at 298. I agree here with Professor Brian Balmer's recent assertion that "[s]ecrecy has never been a major topic of research in social science, although it has not been entirely neglected.” Brian Balmer, Secrecy and Science: A Historical Sociology of Biological and Chemical Warfare (Farnham, UK: Ashgate, 2012) at 2.

7 Erickson \& Flynn, supra note 5 at 252. 
absence of direct coercion. But before such an answer can be fully elaborated, it is first necessary to develop an understanding of how we got to where we are today. What is the genesis of state secrecy? When did it take the form it has today? What contingency made it what it is? Where are we at?

In this article, my aim is to offer a synopsis, or a short narrative of what a genealogy of state secrecy could look like; what its lines of descent can be. In doing so, I will draw on the notion of genealogy originally developed by Michel Foucault which, in contrast to a purely historical approach, is about describing how, or the ways by which a particular phenomenon, in this case the protection of state secrecy, came about, "could have come about, or might be imagined to have come about," 8 and not what the exact origins of the phenomenon are, if that could ever be determined with any degree of accuracy. ${ }^{9}$ A genealogical approach, in its Foucauldian sense, is based on the notion that there are no historical or trans-historical themes, that there are only variations. ${ }^{10}$ Hence, it is about pinpointing the individual differences of a particular historical formation, ${ }^{11}$ given that chance events and historical causality "never ceases to [sweep] along and modify practices, thoughts, customs and institutions." ${ }^{2}$ One way to do that, following Foucault, is to identify the discursive practices, or the discourses, that are significant at a specific point in time, for the reason that discourses vary from historical period to historical period. In every historical period a discourse is taken to be true. As Foucault's friend and historian Paul Veyne explains, "[i]n this way, truth is reduced to telling the truth, to saying whatever conforms with what is accepted as the truth" at the time. ${ }^{13}$ "Foucault's 'discourses'," therefore, can be understood as "spectacles through which, in every age, people have perceived everything, and have thought and acted." ${ }^{14}$ In other words, "[w]hatever is believed to be true elicits obedience." 15 This is an important point. It suggests that one reason individuals do not generally disclose state secrets without authorization would be that they are behaving in accordance with the predominant discourse of their historical period. Using a small selection of authors, I will thusly proceed to show how the protection of state secrecy could have been constructed "in each different epoch (an idea of which its 'discourse' is the ultimate formulation)."16

\section{A BRIEF GENEALOGY OF THE PROTECTION OF STATE SECRECY}

\section{A. Ancient Times}

In ancient culture, practices that involved telling the truth about oneself before others (whether a single interlocutor, the assembly or the prince), called parrhesia, were quite prevalent and the subject of

\footnotetext{
Bernard Williams, Truth and Truthfulness (Princeton: Princeton University Press, 2002) at 20.

9 Paul Veyne, Foucault: His Thought, His Character, translated by Janet Lloyd (Cambridge, UK: Polity Press, 2010) at 107.

$10 \quad$ Ibid at 10.

11 Ibid at 6.

12 Ibid at 35.

13 Ibid at 14.

14 Ibid at 28.

15 Ibid at 93.

16 Ibid at 11. Foucault was not always clear in defining what genealogy was supposed to be about. The way I am using his notion is in line with the first of the three major genealogical approaches in use today. William Walters,

Governmentality: Critical Encounters (London: Routledge, 2012) at 116.
} 
philosophical examination. ${ }^{17}$ Today, such practices are limited to specific sites of investigation; they can be recognized in some forms, for instance in the penitent-confessor, patient-psychiatrist, patientpsychoanalyst and other relationships of that kind. ${ }^{18}$ In studying parrhesia in ancient times, Michel Foucault wanted to explain the relationships between forms of knowledge, relations of power ("the procedures by which people's conduct is governed") and the practices of the self that formed the subject. ${ }^{19}$ Parrhesia, Foucault described, required that the person speaking the truth thought that he was in fact speaking the truth, and that he did so with courage, taking the risk of damaging his relationship with the person(s) to whom he was speaking the truth. ${ }^{20}$ Rhetoric, in contrast to parrhesia, was, and still is, a form of speech, a technique, or a skill, that allowed a good rhetorician to say to others "something completely different from what he knows, believes, and thinks, but of saying it in such a way that, in the final analysis, what he says - which is not what he believes, thinks, or knows-becomes what those he has spoken to think, believe, and think they know." 21 Rhetoric, therefore, was, in my opinion, a technique of concealment, a practice of secrecy, if so used. Parrhesia, however, was not akin only to a technique; it was more than that. It was a way of being, a virtue; it was an obligation to tell others the truth about themselves that they cannot see on their own. ${ }^{22}$ Parrhesia was one of four modes of veridiction (or forms of knowledge) identified by Foucault, the others being prophecy, wisdom, and teaching (or technical, scientific knowledge), that often combined with each other to form different regimes of truth, or modes of discursivity, in different societies. ${ }^{23}$

In its political form, parrhesia occurred in the democratic assembly and between the prince and his counselor. In the latter case, the counselor risked death because there was always a danger that the prince, exercising personal power, could not accept the truth. ${ }^{24}$ As a political parrhesiast, Foucault tells us, the counselor must assert that he is capable of telling the truth, show courage in telling the truth and once he has told the truth let his interlocutor deal with it by himself. Ethical parrhesia by comparison is about subjects taking care of themselves as rational beings "having a relation to truth founded on the very being of" their souls. ${ }^{25}$ An ethical parrhesiast, therefore, encouraged "each individual to take care of himself" and to "practice the examination and confrontation of souls," 26 and taught each to do so by questioning his mode of life, by putting his "mode of life to the test and define what there is in it that may be ratified and recognized as good and what on the other hand must be rejected and condemned." 27 To live a true life, in this context, meant to live a life without concealing anything, without secrecy. ${ }^{28}$ Taking the life of the Cynic as a case in point, Foucault noted that it meant conducting oneself in

17 Michel Foucault, The Courage of Truth: The Government of Self and Others. Lectures at the Collège de France 19831984, ed by Frédéric Gros, translated by Graham Burchell (New York: Palgrave Macmillan, 2012) at 4-5.

18 Ibid at 7.

19 Ibid at 9.

20 Ibid at 11.

21 Ibid at 13 .

22 Ibid at 14, 19, 24.

23 Ibid at 25-26, 28.

24 Ibid at 57-58.

25 Ibid at 86.

26 Ibid at 87.

27 Ibid at 149.

28 Ibid at 218-219, 221. 
conformity with the truth, using self-knowledge for constant vigilance of self over self and supervising others as a matter of solidarity with humankind. ${ }^{29}$ Cynicism as a mode of life was the antithesis of a life imbued with secrecy. As Foucault writes, "what we see emerging through Cynicism is the matrix of what has been a significant form of life throughout the Christian and modern tradition, that is to say, the matrix of a life dedicated to the truth, dedicated to the manifestation of the truth in fact and, at the same time, to veridiction, truth-telling, the manifestation of the truth through discourse.” ${ }^{30}$

\section{B. Early Modern Europe}

In parrhesia, the true discourse produced an unspecified risk to oneself, but a risk nonetheless. ${ }^{31}$ The elimination of that risk was an intended consequence of the discourse on the art of dissimulation that manifested itself in the early modern Europe of the sixteenth and seventeenth centuries. ${ }^{32}$ The emergence of a distinct discourse on dissimulation which effected the practices of self-management and self-representation among the dominant social groups of the Old Regime took place in a period that was marked by the establishment of the modern (then absolutist) state, major social, political, economic and religious changes (e.g., there were six major revolutions in Europe between 1640 and 1650), and across the board, increased social complexity. ${ }^{33}$ It is this discourse on dissimulation, on not "saying something that is or was" and predicated on self-interest, that captivates Jon Snyder as it forms a particular culture of secrecy distinguishable from ancient times and the historical period that followed, characterized by the Romantic revolution and its rhetoric on sincerity, consensus, contract and transparency. ${ }^{34}$

To explain the discourse on dissimulation Snyder analyzed its appearances in the larger discourses on civility, the prince's court, reason-of-state politics and moral philosophy of the dominant groups under absolutism from the pages of published and unpublished Italian treatises and manuals on dissimulation. ${ }^{35}$ In doing so, he discovered that the discourse on dissimulation offered a series of techniques - the disciplined use of reticence, taciturnity, diffidence, negligence, omission, ambiguity, irony and tolerance-through which individuals exercised self-censorship in order to avoid disclosing anything about themselves (their real feelings, what they knew) by way of words, gestures or gaze,

Ibid at 310-312.

$30 \quad$ Ibid at 315.

$31 \quad$ Ibid at 62.

32 Jon R Snyder, Dissimulation and the Culture of Secrecy in Early Modern Europe (Berkeley, CA: University of California Press, 2009).

33 As state and societies grew in complexity, more time was spent in gathering information. This raised a number of interesting questions among commentators at that time. As Snyder remarks, "[i]n this context of ever-increasing circulation, contamination, transformation, and appropriation, how could information best be managed securely and secrets kept by individuals or by governments? Was the truth always to be told? Who was to have the right to keep something hidden, and under what conditions? And how could the practice of secrecy itself be kept secret from others?” Ibid at 4.

34 As Snyder correctly notes: "Dissimulation has not vanished from our world, but it no longer constitutes an art with its own recognized set of rules: its value is merely operational. Today the media-saturated society of the West, built around the principle of publicity, cannot tolerate even the slighest suspicion of dissimulation in those persons who are chosen to be put (profitably) on display.” Ibid at Xx.

35 The Italian focus is explained by the fact that most of the authors who wrote on dissimulation in the sixteenth and seventeenth centuries were Italians. Ibid at xix. 
while simultaneously not lying to others. ${ }^{36}$ This was arduous, especially as dissimulation could not be suspected by others and because of the constant self-examination necessary for self-knowledge, "without which dissimulation was destined to fail."37

The larger discourse on civility made the mastery of dissimulation techniques (including codes of comportment-apparent naturalness, spontaneous grace, warm conviviality, distance from others-and respect for social hierarchy) essential to the constitution of the good society, whereby self-control tames the passions and emotions that would otherwise interfere with the hierarchical structure of social relations and the expected friction-free course of daily social interactions. ${ }^{38}$ Keeping passions and emotions to oneself, however, created suspicion on the part of one's interlocutors as much as it contributed to one's solitude. $^{39}$ At the prince's court, dissimulation practices were equally well entrenched and seen as a sign of support to royal authority. For courtiers, not to follow the appropriate code of comportment could reveal their real intentions or inner lives and as a result affect their ability to obtain or retain power. Courtiers, moreover, had not only to worry about their own self-control but also about the ability of other courtiers to find out what they really thought or intended. ${ }^{40}$

The larger discourse on the reason of state recognized the need for the prince to exercise prudent control over information-primarily in conversations-in the interest of state security and dynastic stability; after all the prince's words and gestures were watched by spies, traitors and enemies of the state, all hoping to discover secrets that would give them an advantage. ${ }^{41}$ This meant at the very least publicly displaying, through self-control of passions, body and language, a lack of knowledge or interest in princely matters. But it was not only the prince who was vulnerable. The prince was also empowered to pry secrets-through "interrogations in the guise of conversations, offers of false friendship in order to gain the confidence of the dissimulator, spies to expose the truths of one's intimate secrets" ${ }^{2}$ - from his subjects to avoid seeing his personal power endangered. The political prudence and dissimulation associated with the reason of state, epitomized by Machiavelli (1469-1527), contrasted with the ancient use of dissimulation, which had to be balanced with parrhesia. For Snyder, the key difference between antiquity and early modern Europe was that dissimulation was no longer the invisible and tacit practice that it was but a practice put into discourse and subject to scrutiny. ${ }^{43}$

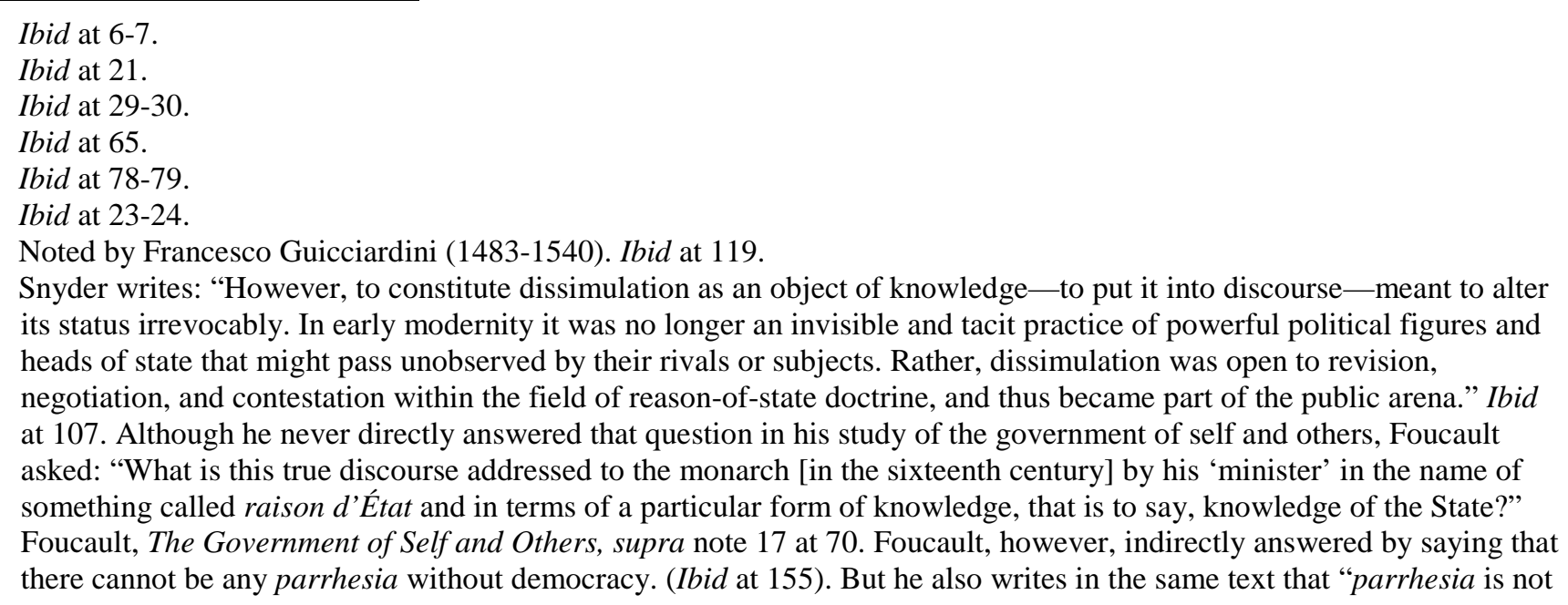


Foucault recognized the distinctiveness of the absolutist period. The manuals and treatises that form the basis of Snyder's study on dissimulation are part of a series that Foucault would categorize as works on the art of government. ${ }^{44}$ This is a series that Foucault saw being concerned, among other issues, about the government of oneself and the government of the state by the prince. With the advent of state centralization and the dispersion of religious dissidence, Foucault believed that the problem that posed itself in this context is "of how to be ruled, how strictly, by whom, to what end, by what methods, etc." 45 Taking Machiavelli's The Prince as the standpoint on the art of government problem, Foucault contrasted its narrative (of the means by which the prince should be able to retain his principality) with alternative narratives on the art of governing which speak of different forms of government, namely the art of self-government (morality) and the art of governing a family (economy). They are all continuous with one another, including governing the state: that is, one must learn to govern himself and his family before being in a position to govern the state, and, conversely, if the state is well governed then one would know how to govern his family well and behave properly. ${ }^{46}$ Foucault also made the point that anti-Machiavellian texts of the $17^{\text {th }}$ and $18^{\text {th }}$ centuries refuted the single, selfish finality of the prince, and instead suggested that the objective of government was to satisfy a plurality of specific aims instead of only imposing the law on all. In doing so, governing the state would also have meant the exercise of wisdom (to have the knowledge of what must be attained and of the associated disposition of things) and diligence (to act in the service of those who are governed) ${ }^{47}$ However, according to Foucault, what affected the art of government of the prince for good, was the emergence of the problem of population (witness the demographic explosion of the $18^{\text {th }}$ century), which interconnected with the science of government and a re-centred (away from the family model) economy. ${ }^{48}$ As Foucault wrote, "the population now represents more the end of government than the power of the sovereign," and as such is also an object in the hands of government to which new tactics and techniques (e.g., policing) would be applied (for example to increase its wealth, ensure its health, etc.). ${ }^{49}$

\section{The Enlightenment and the Transition to the Modern Era}

The discourse on dissimulation under absolutism did not survive the age. Philosophers of the Enlightenment and Romanticism such as Voltaire, Diderot and Rousseau displaced it as a central moral and political concern of dominant social groups, ${ }^{50}$ "all agreed that prudence was a 'sotte virtu' and that dissimulation was immoral. ${ }^{51}$ As Snyder observes:

restricted to operating only within the framework of democracy; a parrhesiastic problem, if you like, a problem of parrhesia arises under any form of government." (Ibid at 212).

Michel Foucault, "Governmentality” in Graham Burchell, Colin Gordon \& Peter Miller, eds, The Foucault Effect:

Studies in Governmentality with Two Lectures by and an Interview with Michel Foucault (Chicago: University of Chicago Press, 1991) 87 at 87.

45 Ibid at 88.

$46 \quad$ Ibid at $91-92$.

47 Ibid at 95-96.

$48 \quad$ Ibid at 99.

49 Ibid at 100.

50 Snyder, supra note 32 at 176.

51 Jacob Soll, Book Review of Dissimulation and the Culture of Secrecy in Early Modern Europe by Jon R Snyder, (2010) 139 H-France Review 616 at 617 [Soll, "Review”]. 
One of the key indices for tracking the shifting ground beneath absolutism is to be found, then, in the growth of the early modern discourse on sincerity. As the previous chapters have argued, anyone in the least ambitious had to know to maintain silence, to wear a mask and to exercise self-dominion in the public domain. However, some did dream of other and better modes of existence, without the endless self-surveillance and wholly instrumental image-management needed to make one's way in the only world that mattered. One such mode-the sincere expression of self-required a reversal of prevalent attitudes toward truth-telling as they pertained to moral (if not religious) experience. $^{52}$

The transition from early modern state secrecy to state secrecy in the modern era is the subject of Alain Dewerpe's Espion: Une anthropologie historique du secret d'État contemporain [translation: Spy: An historical anthropology of contemporary state secrecy]. ${ }^{53}$ Dewerpe contends that each historical period might have dealt with secrecy in its own peculiar and singular forms (as the changes in discourses attest), but that there is something about secrecy (dissimulation, silence) that appears invariable, unaffected by history, and this is the gathering and protection of secrets, in their various and changing manifestations, that can be traced back to antiquity. ${ }^{54}$ In fact, the term "secret of the state" first surfaced in Tacitus's Annals in AD 116, in which it was meant to convey a desire to withhold knowledge and refuse to communicate in order to stabilize and preserve power. ${ }^{55}$ Yet, if slow, changes in secrecy practices through time are not imperceptible; they can be linked to the historical social adaptations that ensure their reproduction or metamorphosis. For Dewerpe, although the Enlightenment displaced state secrecy (for instance through the imposition of the rule of law and the necessity for the prince to publicly account for sovereign decisions), it was only until the last quarter of the $18^{\text {th }}$ century, a period during which state secrecy reasserted a primary but temporary role in politics amidst power politics, imperialism and conflicts that would ultimately lead to the First World War. Philosophers of the Enlightenment age considered all forms of espionage and spies as vile. This sentiment abated with the $19^{\text {th }}$ century-consolidation of the nation-state that imposed new values giving espionage and spies a more positive image: they were, after all, necessary evils (espionage between private individuals, however, remained immoral). State secrecy and espionage, therefore, found legitimacy in their purpose:

52 Snyder supra note 32 at 161-162.

53 Alain Dewerpe, Espion: Une anthropologie historique du secret d'État contemporain (Paris: Éditions Gallimard, 1994).

54 Ibid at 11. Other historians would readily support Dewerpe. The key sources for Antiquity are: Frank S Russell, Information Gathering in Classical Greece (Ann Arbor, MI: The University of Michigan Press, 1999); Rose Many Sheldon, Intelligence Activities in Ancient Rome: Trust in the Gods, but Verify (London: Frank Cass, 2005); and Ralph D Sawyer, The Tao of Spycraft: Intelligence Theory and Practice in Traditional China (Boulder: Westview Press, 1998). The literature on both Ancient Greece and Ancient Rome is extensive. See Rose Mary Sheldon, Espionage in the Ancient World: An Annotated Bibliography (Jefferson, NC: McFarland, 2003). However, while the desire to know about one's adversary goes back to Antiquity, it was only in the second half of the $19^{\text {th }}$ century that the gathering of intelligence took the form of a special discipline incorporating the bureaucratization of secrecy. Dewerpe, ibid at 221-222.

55 Eva Horn, “Logics of Political Secrecy” (2011) 28:7-8 Theory, Culture \& Society 103 at 107. 
it was for the civic good, for the nation (instead of the person of the prince), that spies were risking their lives gathering information that only the state would know about. ${ }^{56}$

Dewerpe's aim in writing his book was to uncover the conditions that make state secrecy possible amidst a political culture with a strong transparency component. His is a rich narrative that touches upon all aspects of intelligence tradecraft and their evolution over the past two centuries. Along the way, he made interesting observations on the role of law. He writes thusly that matters of state secrecy and espionage were outside the realm of the law until the second part of the $19^{\text {th }}$ century. International law interested itself first in these matters at the turn of the $20^{\text {th }}$ century because they were interwoven with law of armed conflict issues. National law for its part had difficulty articulating what secrecy was, how to protect it adequately, and what offences to punish. The law in most countries would eventually come to adopt strict provisions that would punish crimes against the security of the state, including the intentional and non-intentional disclosure of state secrets, not only in time of war but in peacetime as well. By the 1950s another shift was discernible in the law of a select number of liberal democracies. Punishing the disclosure of state secrets would gradually be based on the extent of the damages caused by an unauthorized disclosure rather than the secretive nature of the information itself. ${ }^{57}$ In addition to the legalization of the unauthorized disclosure of state secrets, the increased bureaucratization of the state throughout the late $19^{\text {th }}$ and the $20^{\text {th }}$ centuries and the establishment of professional organizations solely dedicated to the creation and the use of secrets also contributed to further entrenching state secrecy within the liberal state. ${ }^{58}$ State secrecy practices, in other words, had become highly technical, which have allowed their practitioners to claim efficiency and rationality.

Dewerpe is correct, but there was an interesting precedent that he did not explore. While the discourse of dissimulation was characteristic of the absolutist age, so was the sophistication of the mechanisms of administration relied upon by the absolutist state and its merchants. Public and secretive administrative practices, Jacob Soll contended in his work on Jean-Baptiste Colbert (1619-1683), ${ }^{59}$ were as important as the discourses on dissimulation, prudence and the reason of state to understand early modern political and ethical culture. ${ }^{60}$ The advent of the modern, secular and rational administrative state, however, cannot be attributed to the significance of Colbert's effort alone, notwithstanding the influence and power he wielded and his successes at gathering information. ${ }^{61}$ Colbert, as Louis XIV's prima inter pares minister, in particular built upon the traditions of the Church and merchants, the archival practices of the Republic of Venice and the knowledge and expertise of scholars in his quest for centralized information — a central secret state archive-the purpose of which would be to support and

56 Dewerpe, supra note 53 at 23, 25, 27, 32, 34.

57 Ibid at 36-37, 46-50, 54.

58 Ibid at 120.

59 Jacob Soll, The Information Master: Jean-Baptiste Colbert's Secret State Intelligence System (Ann Arbor, MI: The University of Michigan Press, 2009). Colbert was Louis XIV’s Controller-General of Finances from 1665 to 1683 [Soll, Information Master].

60 Soll, "Review", supra note 51 at 618.

61 As Soll notes, "With the resources of a nation-state at his disposal, Colbert the bibliophile administrator, accountant, and founder of academies amassed enormous libraries and state, diplomatic, industrial, colonial, and naval archives; hired researchers and archival teams; founded scientific academies and journals; ran a publishing house; and managed an international network of scholars.” Soll, Information Master, supra note 59 at 7. 
further the king's royal prerogatives and power. ${ }^{62}$ His contribution to state governmental culture, Soll asserted, was to show Louis XIV "how he could dominate and use the world of learning not only as a source of public propaganda, but also as a tool of secret government." ${ }^{33}$ More importantly, Colbert's information management practices, as a case study, demonstrate that an understanding of the history of information, predominantly focused on the public sphere, necessitates the study of the history of state secrecy. ${ }^{64}$ Colbert's "new technical type of government expertise" ${ }^{35}$ was not institutionalized or bureaucratized; it "died with him," ${ }^{, 6}$ at least in France. Upon Colbert's death, Louis undid Colbert's centralized state and archives and placed himself at the centre of the state. Divide and rule and secrecy were the principles by which he governed through the remainder of his reign. ${ }^{67}$ Elsewhere in Europe in the eighteenth century, however, Colbert's vision of learned administration was emulated by states such as Prussia, Spain, Austria, Tuscany, Portugal and Russia: the idea that large states need centralized information to govern effectively had taken roots. ${ }^{68}$

The bureaucratization of secrecy, however, has been challenged and problematized in very different terms. Karl Marx (1818-1883) made the simple but still powerful point that the control of knowledge, and therefore secrecy, was a fundamental characteristic of the bureaucracy:

The bureaucracy is a magic circle from which no one can escape. Its hierarchy is the hierarchy of knowledge [...]. The bureaucracy holds the state, the spiritual essence of society, in thrall, as its private property. The universal spirit of bureaucracy is secrecy. ${ }^{69}$

From a traditional Marxist understanding, state or administrative secrecy is a necessary concealment mechanism that the capitalist state uses to give legitimacy to an exploitative accumulation process. ${ }^{70}$ As such, it can directly serve the private sector in that task. ${ }^{71}$ Not surprisingly, the Marxist philosophers and

$62 \quad$ Ibid at 3.

$63 \quad$ Ibid at 7.

64 Ibid at 10-11.

65 Ibid at 52.

66 PC Reynard, Book Review of The Information Master: Jean-Baptiste Colbert's Secret State Intelligence System by Jacob Soll, (2010) 158 H-France Review at 690.

67 Soll, Information Master, supra note 59 at 154. As Soll notes: “Although after Colbert's death, Louis XIV’s ministers were collecting more information than before, the motive behind the collection was clearly not the rational, centralized functioning of the state, but rather a complex set of competing interests between various ministerial lobbies, which had been, to varying degrees, the nature of European state administration since the Middle Ages.” (Ibid at 159). As for secrecy, he adds that "the secret royal sphere atrophied into the world of spying, failed finance, and despotic fiat." (Ibid at 165).

68 Ibid at 162.

69 Karl Marx, “The Critique of Hegel’s Doctrine of the State,” in Early Writings (Harmondsworth, UK: Penguin, 1974) at 107, quoted by Kiern Allen, Max Weber: A Critical Introduction (London, UK: Pluto Press, 2004) at 148.

70 Claus Offe, “The Theory of the Capitalist State and the Problem of Policy Formation” in Leon Lindberg, ed, Stress and Contradiction in Modern Capitalism (Lexington, MA: D. C. Heath, 1975) 125 at 127, as discussed by Clyde W Barrow, Theories of the State: Marxist, Neo-Marxist, Post-Marxist (Madison, WI: The University of Wisconsin Press, 1993) at 101.

71 As Samuel Weber notes: "There are plenty of secrets and obscurities today-perhaps more than ever before-but what is not obscure, to anyone with the ability to reflect upon it, is the finality of those secret and obscure institutions and strategies: namely, the unending accumulation of wealth, real and 'fictive', by an ever-smaller percentage of the global 


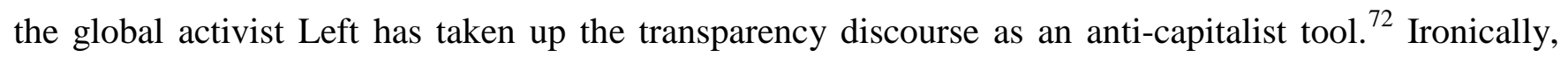
Marxists were not self-reflexive and failed to condemn the use of secrecy in Marxist revolutionary movements and non-capitalist, communist systems. ${ }^{73}$ As philosopher Bertrand Russell observed, Communist and anarchist organizations, among others, were akin to secret societies, and secrecy can contribute to despotism. ${ }^{74}$ Notwithstanding, Marx’s original point has a lot of currency today. In fact, even non-Marxists can appreciate that secrecy is a bureaucratic characteristic which has become "the reigning force in governments around the world-both elected and non-elected." 75 The reasons why, of course, have not necessarily to do with supporting the capitalist mode of production. They are also about open government and the detrimental effects it may have on the activities of bureaucrats. As B. Guy Peters explains,

[s]ecrecy has been adopted quite simply to ensure that administrators as public servants will be isolated from short-term political pressures and be free to make decisions in what they consider to be the 'public interest. ${ }^{, 76}$

Secrecy, the argument further goes, allows bureaucracies to be neutral, and more effective and autonomous than they would if everything they do were transparent. ${ }^{77}$ In a context where their advice is privileged, bureaucrats are more likely to express themselves freely and frankly with both their subordinates, colleagues and superiors: "unless such an exchange of ideas, trying out of proposals, and general brainstorming is kept confidential, the whole process of reaching a reasoned decision is acutely impeded." 78 Political theorist Carl Schmitt (1888-1985) thought along these lines too, arguing that secrecy is a core function of government without which it would be subjected to constant debate that would affect its ability to operate. ${ }^{79}$ The downside to this is that official secrecy has allowed bureaucrats to monopolize knowledge and expertise in the protection of its own interests and to become "an

population (and this holds even for those countries and areas of the world that are undergoing rapid economic development). Thus, the 'secret' is increasingly placed in the service of private appropriation [...].” John WP Phillips, "Secrecy and Transparency: An Interview with Samuel Weber” (2011) 28:7-8 Theory, Culture \& Society 158 at 169. Clare Birchall, “Transparency, Interrupted: Secrets of the Left” (2011) 28:7-8 Theory, Culture \& Society 60 at 62.

73 By the late 1980s the local hoarding and hiding of information prevented Communist leaders from fully appreciating the failures of their policies and hence from taking measures that would have been necessary to preserve their political and social system and preserving control over government assets. Hilton L Root \& Karen May, "Judicial Systems and Economic Development” in Tom Ginsburg \&Tamir Moustafa, eds, Rule by Law: The Politics of Courts in Authoritarian Regimes (Cambridge, UK: Cambridge University Press, 2008) 304 at 313.

74 "Under an autocratic government, men who aim at any radical change are driven to secrecy, and, when they combine, fear of treachery leads to a very strict discipline. It is natural to demand a certain way of life, as a safeguard against spies. The risk, the secrecy, the present suffering, and the hope of future triumph, produce a quasireligious exaltation, and attract those to whom this mood comes easily. Hence within a revolutionary secret society, even if its aim is anarchism, there is likely to be a very severe despotism, and a supervision extending far beyond what would usually be considered political activity.” Bertrand Russell, Power: A New Social Analysis (London, UK: Routledge, 2004) at 139.

75 Judith Allen, Virginia Woolf and the Politics of Language (Edinburgh: Edinburgh University Press, 2010) at 3.

76 B Guy Peters, The Politics of Bureaucracy, $5^{\text {th }}$ ed (London, UK: Routledge, 2001) at 309.

77 Neil Robinson, "Bureaucracy" in Paul Barry Clarke \& Joe Foweraker, eds, Encyclopedia of Democratic Thought (London, UK: Routledge, 2001) at 43.

78 Thomas I Emerson, “The Danger of State Secrecy”, The Nation (30 March 1974) 395 at 398.

79 Horn, supra note 55 at 114. 
independent social and political force within modern capitalist political economies and societies." ${ }^{\text {80 }}$ This is an argument that Max Weber explicitly made, especially when he wrote, with respect to Germany, that

officialdom's most important instrument of power is the transformation of official information into secret information by means of the infamous concept of 'official secrecy', which ultimately is merely a device to protect the administration from control. ${ }^{81}$

The official secret, from that standpoint, is thus nothing less than a specific invention of the bureaucracy that serves its pure interest. ${ }^{82}$ How these interests are served often feeds the imagination of conspiracy theorists who argue that state activities done under the cover of secrecy must be so sinister that they have to be concealed from the public. ${ }^{83}$ Hence, Weber recognized the power of bureaucracies, especially as they could affect "the ideals of freedom and individuality in the West," and argued that democratic institutions were best suited in keeping this power in check. ${ }^{84}$ Here Weber was referring to British parliamentary practices whereby public servants could be compelled to testify under oath. ${ }^{85}$ This strand of arguments as they relate to the notion of bureaucratic self-interest suggests that keepers of state secrets would recognize that interest and hence not disclose secrets without authorization because doing so would be against their self-interest. If it were true and compelling most of the time, there would be little need for the repressive power of the law to mete out harsh punishments for unauthorized disclosure, or for government to put in place an elaborate assemblage of policies, practices and discourses/rationalities to control and influence the behaviour of keepers of state secrets.

This little excursus on bureaucracy and secrecy is an example of the direction of social change occurring alongside a mutating discourse leading, paradoxically, into the age of transparency. It is indeed a combination of circumstances between "seemingly unconnected fields of social activity" ${ }^{86}$ that has given rise to the contemporary practices of state secrecy. It is also a competing narrative focused on the self-interest of bureaucrats, a class of subjects to which the keepers of state secrets belong.

80 Michael Reed, “Beyond the Iron Cage? Bureaucracy and Democracy in the Knowledge Economy and Society” in Paul du Gay, ed, The Values of Bureaucracy (Oxford: Oxford University Press, 2005) at 122.

81 Max Weber, Political Writings (Cambridge UK: Cambridge University Press, 1994) at 179. See also, inter alia, Max Weber, The Theory of Social and Economic Organization, Talcott Parsons, ed (Glencoe, IL: The Free Press, 1947) at 339; Max Weber, From Economy and Society: An Outline of Interpretive Sociology, Guenther Roth \& Claus Wittich eds, translated by HH Gerth \& C Wright Mills, rev by Guenther Roth \& Claus Wittich, slightly rev by Stephen Kalberg (Berkeley: University of California Press, 1978) at 989-994.

82 Max Weber, "Bureaucracy” in HH Gerth \& C Wright Mills, ed \& trans, From Max Weber: Essays in Sociology (New York: Oxford University Press, 1946) at 233.

83 Michael Barkun, A Culture of Conspiracy: Apocalyptic Visions in Contemporary America (Berkeley: University of California Press, 2003) at 4.

84 Ahmad Sadri, Max Weber's Sociology of Intellectuals (New York: Oxford University Press, 1992) at 93.

85 Fritz Ringer, Max Weber: An Intellectual Biography (Chicago: University of Chicago Press, 2004) at 67.

86 Alan Hunt \& Gary Wickham, Foucault and Law: Towards a Sociology of Law as Governance (London: Pluto Press, 1994) at 6. 


\section{The Age of Transparency}

Our modern political culture favours publicity and transparency in public matters and distrusts what cannot be subjected to public scrutiny. "We live in an age of transparency," political science professor Kristin Lord proclaimed in 2006. ${ }^{87}$ This is an age that has substituted the logic of secretum (secret seal)_secretum referring to the relationship between those who know and those who don't, and between those who suspect and those who are supposed to know-for the arcana imperii (invisible power). This is a logic about social exclusion and inclusion and the "secrecy effect" that philosopher Jacques Derrida has described. ${ }^{88}$ In the simpler words of Eva Horn, Derrida's "secrecy effect" is the "the awareness (or belief or suspicion) that a secret exists, which, especially in the context of power relations, can have a greater impact than a real secret." 89 The existence of an actual secret is therefore not essential; it is about its supposition. The holder of a real or supposed secret derives his/her power over others because of the potential of future disclosure. ${ }^{90}$ Absolute transparency would, concretely, deny a right to the secret, and, to Derrida, this intolerance for singularity would make transparency look like a tool of totalitarianism. ${ }^{91}$

In democratic societies, transparency is usually seen as the opposite of secrecy. Total transparency, a utopian concept if any, means “a sphere of truth untainted by doubts and lies."92 For Samuel Weber, secrecy and transparency are not mutually exclusive opposites because both are about accessing something or someone. In fact, both terms may recognize the same phenomenon, for instance when something is hidden in plain view. Secrecy and transparency are therefore best understood in terms of relations and processes to be interpreted instead of being about self-contained objects. While recognizing that demands for transparency could matter a great deal in the defence of democracy, transparency as such need not always be a response to secrecy, as it often responds instead to historically conditioned social, political or cultural desires (that originated with philosophers of the Enlightenment). ${ }^{93}$ Eva Horn also argues that secrecy and transparency are not absolute opposites. In the reality of day-to-day government practice, secrecy "serves to protect and stabilise the state, and as such it is the precondition for the functioning of the law." 94 However, while secrecy has legitimate roles, it "opens a space of exception from the rule of law, an exception that can breed violence, corruption and oppression." "95 It follows, argues Horn, that secrecy is in effect a paradox, a complement and precondition to transparency. ${ }^{96}$ Horn's perspective, coupled with Schmitt's ("ignoring the law in order to allow it to become effective"), ${ }^{97}$ allows for a functionalist view of secrecy and the foreclosing of

87 Kristin M Lord, The Perils and Promise of Global Transparency: Why the Information Revolution May Not Lead to Security, Democracy, or Peace (Albany: State University of New York Press, 2006) at 5.

88 Jacques Derrida, “To Do Justice to Freud': The History of Madness in the Age of Psychoanalysis” in Arnold I Davidson, ed, Foucault and His Interlocutors (Chicago: University of Chicago Press, 1997) 57 at 75. Horn, supra note 55 at 109.

$90 \quad$ Ibid at 109.

91 Clare Birchall, “Introduction to 'Secrecy and Transparency’: The Politics and Opacity and Openness” (2011) 28:7-8 Theory, Culture \& Society 7 at 12.

92 Phillips, supra note 71 at 159.

93 Ibid at 161, 164-165, 167.

94 Horn, supra note 55 at 106.

95 Ibid.

96 Ibid.

97 Ibid at 117. 
moral or legal concerns. It does not, however, resolve the ambivalence of secrecy and its intentional negative effects (such as those occasioned by covert actions, interventions in other states, abductions, rendition, torture, etc.). ${ }^{98}$ On this point, state secrecy certainly has been a prominent feature of many post-9/11 measures taken against known and suspected terrorists, and regularly assailed by civil libertarians and others because of the harm it can cause to innocent people and of its negative impact on the integrity of our democratic system. ${ }^{99}$ For instance, the invocation of a non-disclosure privilege for national security reasons in court proceedings is troublesome to defence lawyers and civil libertarians because it precludes a defendant from having the evidence against him or her tested in a full, open and adversarial hearing. The necessity to protect intelligence information from disclosure has led to increased tensions with the normally recognized democratic requirements of transparency, accountability and procedural fairness. This does matter because of the long-established principle

that all acts of government must be open to public scrutiny [...] not only [...] to permit the citizen to be aware of the acts of those in power and hence control them, but also because public scrutiny is itself a form of control, is a device which allows distinctions to be made between what is permissible and what is not. ${ }^{100}$

Perhaps more incisively, Larry Alexander wrote that,

Cloaking ideas and information in secrecy encourages ignorance, corruption, demagoguery, a corrosive distrust of authority, and a historical memory resembling Swiss cheese. Open discussion, on the other hand, allows verities to be examined, errors to be corrected, disagreement to be expressed, and anxieties to be put in perspective. It also forces communities to confront their problems directly, which is more likely to lead to real solutions than covering them up. ${ }^{101}$

There is no denying that the negative or harmful effects that Alexander associates with secrecy are oftentimes observed. Although he is correct on that point, his reluctance to countenance that there are state secrets that, demonstrably, are necessary and legitimate, say for national security purposes (e.g., in times of war) or to protect the privacy of citizens, does not make for a well-balanced argument. In his discussion on publicity in the context of British parliamentary proceedings, philosopher Jeremy Bentham (1748-1832), who saw secrecy as an instrument of conspiracy, made the important point that publicity cannot be an absolute principle and that there were circumstances where it ought to be suspended in order to prevent an enemy to gain an advantage, "to injure innocent persons" and "to inflict

$98 \quad$ Ibid at $115-116$.

99 I understand the harm a state can cause as "an invasion by a state agency of any person's basic welfare interests, whether such invasion is justified or not;” basic welfare interests being defined as "interests in those elements of freedom and wellbeing that are necessary for human beings to function effectively as purposive agents. They include such things as life, physical and mental health, freedom from severe pain, freedom from confinement or coercion, and sufficient education and financial resources to enable one to play a part in the life of one's society.” Tony Ward, "State Harms” in Paddy Hillyard et al, eds, Beyond Criminology: Taking Harm Seriously (London: Pluto Press, 2004) at 85-86.

100 Bobbio, supra note 4 at 34.

101 Larry Alexander, Is There a Right of Freedom of Expression? (Cambridge, UK: Cambridge University Press, 2005). 
too severe a punishment upon the guilty." 102 Benedict de Spinoza (1632-1677) had preceded Bentham in arguing that state secrecy should only be evoked in exceptional circumstances, and that it is preferable "for the honest policies of a state to be obvious to its enemies than for the guilty secrets of tyrants to be kept hidden from its citizens.” 103 Philosopher John Stuart Mill (1806-1873) shared the views of Spinoza and Bentham, adding that the public and open discussion of ideas is essential for arriving at the truth. ${ }^{104}$ The problem, of course, is that claims to national security confidentiality can be made with respect to issues that only have a tenuous link to national security. In a post-9/11context, to prevent terrorists from obtaining any information (for instance on potential targets' vulnerabilities) that they could use to cripple the United States and other democratic nations, state secrecy has expanded its coverage exponentially, in particular in the areas of science \& technology and economics. ${ }^{105}$

Yet, the reluctance to countenance that there are state secrets is taken for granted by a large majority of the populations of democratic countries who see daily expressions of such a view in media speculations, television dramas and works of fiction. ${ }^{106}$ In short, secrets and their disclosure interest and fascinate the public, who pressure governments for greater transparency, a concept that has taken the overtone of a universal democratic standard and even, in the view of a few experts and the InterAmerican Court of Human Rights, of a human right. ${ }^{107}$ Democratic governments have favourably, if only generally, responded to such pressures with the adoption, for example, of access to information legislation. But their lingering attempts to contain the flow of information is seen by segments of the public as the new censorship. As Dave Boothroyd explains:

102 Jeremy Bentham, in Stephen G. Engelmann, ed, Selected Writings by Jeremy Bentham (New Haven: Yale University Press, 2011) at 302.

103 Benedict de Spinoza, Tractatum Theologico-Politicus, chapter VII, paragraph 29, R.H.M. Elwes, translator, The Chief Works of Benedict de Spinoza (London, UK: George Bell and Sons, 1891) at 342.

104 John Stuart Mill, On Liberty, in JM Robson, ed, Collected Works of John Stuart Mill, Vol. 18 (Toronto: University of Toronto Press, 1977) 213-310. Noted by Cynthia Bisman, "Personal Information and the Professional Relationship: Issues of Trust, Privacy and Welfare” in Chris Clark \& Janice McGhee, eds, Private and Confidential? Handling Personal Information in Social and Health Services (Bristol, UK: Policy Press, 2008) 17 at 19.

105 Benjamin W Cramer, "The Power of Secrecy and the Secrecy of Power: FACA and the National Energy Policy Development Group” (2008) 13 Comm L \& Pol’y 183 at 226; Jacob N Shapiro \& David A Siegel, “Is this Paper Dangerous? Balancing Secrecy and Openness in Counterterrorism” (2010) 19 Security Studies 66 at 67-68.

106 As Horn observed, "the modern state secret is [...] a constant source of speculation, dramatization and fictionalization." Horn, supra note 55 at 118. In the modern mass-communication society, secrecy is an object of public desire. In the view of Jodi Dean, "the modern mass-communication society is characterized by an ideology of openness and antihegemony, but driven in fact by a mix of secrecy and spectacle.” Within this political economy, she argues, "secrecy becomes both a locus of economic value and the object of public desire. The desire to expose secrets feeds a public culture of the spectacle, which neither satiates the desire nor dislodges the power that secrets represent.” This summary of Dean's thinking is from Julie E Cohen, Configuring the Networked Self: Law, Code, and the Play of Everyday Practice (New Haven: Yale University Press, 2012) at 208. Dean's work is Publicity’s Secret: How Technoculture Capitalizes on Democracy (Ithaca: Cornell University Press, 2002).

107 Dave Boothroyd, “Off the Record: Levinas, Derrida and the Secret of Responsibility” (2011) 28:7-8 Theory, Culture \& Society 41 at 42-43; Birchall, supra note 91 at 62; Suzanne J Piotrowski, "What Is Transparency?” in Suzanne J Piotrowski, ed, Transparency and Secrecy: A Reader Linking Literature and Contemporary Debate (Lanham, Md: Rowman \& Littlefield Publishers, 2010) 1 at 2. 
In this cultural context, 'the secret' becomes the name of what is, supposedly, deliberately and consciously withheld by means of security informational sub-systems designed to keep secrets secret, which, in turn, themselves are only disclosed and become known (and thus matters of the overtly 'public record') on the basis of their own breaches, or technical failures. It is in this way that the dominant concept of the secret for the public remains restricted to the notion that 'they', or someone somewhere, possess a potentially exposable and shareable secret. ${ }^{108}$

The principle that governments be opened to public scrutiny, including with respect to national security, is now a generally accepted and essential characteristic of liberal democratic systems of government. ${ }^{109}$ Without any possibility of scrutiny the public would have to submit to a decision as a matter of force rather than of persuasion, ${ }^{110}$ and therefore would lose one avenue of control, and as Norberto Bobbio argues, "democracy, in the sense of visible government, is lost."111 This "shortage of information about government activities reduces public debate and understanding about public issues," 112 and prevents the development of trusted cooperative relationships between the governors and governed.

The ways by which our Canadian legislative and judicial institutions have tried to balance the tension between state secrecy and transparency has been contentious and a satisfactory balance has yet to be achieved. ${ }^{113}$ As Kent Roach argues, the Canadian government, since 9/11, has overclaimed the secrecy privilege, ${ }^{114}$ with the effect that it has become difficult to judge the government's claims on their own

108 Boothroyd, supra note 107 at 52-53.

109 There may only be temporary exceptions for public security reasons, a notion which by now has a long history. For example, in the $18^{\text {th }}$ century, the bishop of Vico, Michele Natale, wrote that "Is there nothing secret in Democratic Government? All the activities of those in power must be known to the Sovereign People, except for some measures of public security, details of which must be divulged once the danger has ceased.” M Natale, Catechismo reppublicano per I'istruzione del popolo e la rovina de'tiranni, in the recent edition of G. Acocella (Vico Equense, 1978) at 71, cited in Bobbio, supra note 4 at 81.

110 Emerson wrote: "to the extent that information is withheld from a citizen the basis for government control over him becomes coercion, not persuasion. The citizen is given no rational ground for accepting a decision; he must submit to it as a matter of force.” Emerson, supra note 78 at 395.

111 Bobbio, supra note 4 at 34 .

112 Cramer, supra note 105 at 225. Cramer attributed this argument to Sissela Bok, Secrets: On the Ethics of Concealment and Revelation (New York: Vintage Books, 1983) at 189.

113 For a more elaborate discussion, see, inter alia, Stéphane Lefebvre, “Canada’s Legal Framework for Intelligence” (2010) 23 International Journal of Intelligence \& CounterIntelligence 247; Kent Roach, "When Secret Intelligence Becomes Evidence: Some Implications of Khadr and Charkaoui II” (2009) 47 (2d) Sup Ct L Rev 147; Gus van Harten, "Weaknesses of adjudication in the face of secret evidence" (2009) 13 International Journal of Evidence \& Proof 1; and Colleen Bell, "Subject to Exception: Security Certificates, National Security and Canada’s Role in the 'War on Terror'” (2006) 21 CJLS 63.

114 Kent Roach, The 9/11 Effect: Comparative Counter-Terrorism (Cambridge, UK: Cambridge University Press, 2011) at 420. 
merit. ${ }^{115}$ Yet, there are no normative theories to help one decide when more transparency is preferable to more secrecy. ${ }^{116}$

Contemporary demands for transparency, however, are not about the absolute elimination of state secrecy: they are about redefining its boundaries in a shifting world while recognizing that the liberal democratic state needs a relatively small degree of secrecy to be effective. This is the result of two centuries of political transformations that have brought back the need for transparency and of an open market for ideas. ${ }^{117}$

\section{TODAY'S PARADOX}

Where are we now? Keepers of state secrets are in a paradoxical situation. They are expected by their government employer to obey the law and hence not to disclose state secrets without authorization. Yet, as members of Canadian society they are not immune from social influences and developments that may influence their sense of loyalty and duty to obey the law. Increased zones of secrecy in advanced democracies, arguably made necessary in the name of national security, contribute, according to political scientist Wendy Brown, to a de-democratization of state action. ${ }^{118}$ The breach of "commonly accepted moral standards" cloaked in secrecy has been a contributing factor to the cynicism of citizens about the political process of today's democratic polities. ${ }^{119}$ Of international relations, national defence and national security, the latter is especially clouded in secrecy. This is problematic because the population, having no other option, must place its trust and faith in governments' assessments of threats to Canada's national security, which rely on intelligence (state secrets) that can only be seen by individuals determined by government to have a specific need to know. The courts in advanced democracies, including Canada, have themselves usually deferred to the national security expertise of governments to assess threats. ${ }^{120}$ Taken for granted, these assessments serve as rationales for the imposition of security

115 When there is too much secrecy, the slide toward a despotic regime is not far off. John Ferejohn \& Pasquale Pasquino, “The Law of the Exception: A Typology of Emergency Powers” (2004) 2:2 International Journal of Constitutional Law at 232.

116 Even Alasdair Roberts, in one of the few in-depth analysis of government secrecy in the information age (Alasdair Roberts, Blacked Out: Government Secrecy in the Information Age (Cambridge, UK: Cambridge University Press, 2006), did not offer "a workable theory for when transparency is appropriate in the face of the competing demands for homeland and national security." Peter P Swire, Book Review of Blacked Out: Government Secrecy in the Information Age by Alasdair Roberts, (2007) 23:2 Issues in Science \& Technology 92 at 92.

117 Dewerpe, supra note 53 at 12-14, 81, 115.

118 Wendy Brown, “'We Are All Democrats Now...”” in Giorgio Agamben et al, Democracy: In What State? (New York: Columbia University Press, 2011) 44 at 50.

119 "[T]he prevalence of such secrecy, especially with regard to the breach of commonly accepted moral standards, is corrosive of the basic ideals of a democracy, and productive of cynicism about the political process. Witness the effects of the many, decidedly unnecessary moral enormities (including torture and support for terrorism) committed, without adequate scrutiny, under the rubric of 'national security' by so many Western democracies in recent years.” CAJ Coady, "Dirty Hands” in Robert E. Goodin, Philip Pettit \& Thomas Pogge, eds, A Companion to Contemporary Political Philosophy, 2d ed, Volume 1 (Oxford: Blackwell Publishing, 2007) 532 at 537.

120 As noted in Canada (Attorney General) v Canada (Commission of Inquiry into the Actions of Canadian Officials in Relation to Maher Arar) (F.C.), 2007 FC 766, [2008] 3 FCR 248 at paragraph 46: "It is trite law in Canada, as well as in numerous other common-law jurisdictions, that courts should accord deference to decisions of the executive in what concerns matters of national security, national defence and international relations, as the executive is considered to have 
measures that could be disproportionate to the threat posed and, where individuals are concerned, affect civil and human rights. ${ }^{121}$ Serious arguments have indeed been made by scholars that the post-9/11 threat from terrorism has in many instances been overblown, ${ }^{122}$ including for the bureaucratic benefit of intelligence agencies themselves. ${ }^{123}$

Because the beliefs of government officials and the rationales behind government decisions cannot be publicly known when they involve state secrecy, it directly follows that government officials cannot be directly challenged and debated on the public square. State secrecy in advanced democracies thus impedes the discussion of issues that otherwise would be debated when they have the potential to affect the population or specific individuals. This further misconstrues the meaning of living in a free society that we take for granted. But this is not all. State secrecy claims also affect the ability of the judiciary to conduct its proceedings openly and transparently (the "open court principle"), and prevents defendants from fully knowing the reasons behind their legal problems. The more overbroad these claims are, ${ }^{124}$ and the less public scrutiny there is for the actions of government, the greater likelihood of public distrust, suspicion and cynicism about government claims. The Canadian judiciary has shown concerns about state secrecy claims and has strived to manage court proceedings in line with the open court principle. Notwithstanding this honourable intent, judges must conduct secret court proceedings if required to by the Canada Evidence Act, which essentially eliminates the adversary system in the

greater knowledge and expertise in such matters than the courts.” For an analysis of a number of democratic jurisdictions, see Iain Scobbie, “The Last Refuge of the Tyrant'? Judicial Deference to Executive Actions in Time of 'Terror'” in Andrea Bianchi \& Alexis Keller, eds, Counterterrorism: Democracy's Challenge (Oxford: Hart Publishing, 2008) 277.

121 Anastassia Tsoukala, “Defining the Terrorist Threat in the Post-September 11 Era” in Didier Bigo \& Anastassia Tsoukala, eds, Terror, Insecurity and Liberty: Illiberal Practices of Liberal Regimes After 9/11 (London: Routledge, 2008) 49 at 80-81. Some of this intelligence is sometimes made available in small portions through the public testimony of government officials or access to information legislation. The proportionality of any measure taken as a result of a government threat assessment, however, is arguably within the purview of courts in advanced democratic countries. Scobbie, supra note 118.

122 See, inter alia, Chaim Kaufmann, "Threat Inflation and the Failure of the Marketplace of Ideas: The Selling of the Iraq War” (2004) 29:1 International Security 5; Jenny Hocking, Terror Laws: ASIO, Counter-Terrorism and the Threat to Democracy (Sydney: University of New South Wales Press, 2004); Alan Doig \& Mark Phythian, “The National Interest and the Politics of Threat Exaggeration: The Blair Government's Case for War Against Iraq” (2005) 76:3 Political Quarterly 368; John Mueller, “Simplicity and Spook: Terrorism and the Dynamics of Threat Exaggeration” (2005) 6:2 International Studies Perspectives 208; John Mueller, Overblown: How Politicians and the Terrorism Industry Inflate National Security Threats, and Why We Believe Them (New York: Free Press, 2006); Ted Gup, Nation of Secrets: The Threat to Democracy and the American Way of Life (New York: Doubleday, 2007); Trevor Thrall \& Jane K Cramer, eds, American Foreign Policy and the Politics of Fear: Threat Inflation Since 9/11 (London, UK: Routledge, 2009); and Jeffrey Monaghan \& Kevin Walby, “Making up ‘Terror Identities’: Security Intelligence, Canada’s Integrated Threat Assessment Centre and Social Movement Suppression” (2012) 22:1 Policing and Society 133.

123 Laurent Bonelli, “Hidden in Plain Sight: Intelligence, Exception and Suspicion After 11 September 2001 ” in Bigo \& Tsoukala, supra note 121,100 at 108-109.

124 In their 2006 paper on national security allegations, lawyers Richard Dearden and Wendy Wagner provided several examples of government overbroad abuses. Richard G Dearden \& Wendy J Wagner, "The New Threat to Access to Information: National Security Allegations” (Paper delivered at the 2006 Law \& Parliament Conference on Accountability as a Pillar of Democratic Governing, 2006) at 2-3, 19 [published in (2008) 1 J. Parliamentary \& Pol L 457] 
adjudication of claims. ${ }^{125}$ In their 2006 paper on state secrecy claims, lawyers Dearden and Wagner took no comfort in the notion that the final say on these claims ultimately rests in the hands of an elected politician, notwithstanding an appointment as Attorney General. ${ }^{126}$ They concluded from their examination of relevant post-9/11 cases that "[n]ational Security is an exception to those principles [of openness and accountability] and can only be invoked when 'necessary' as opposed to when it is 'convenient' for our government and law enforcement officials to invoke it., 127

The state secrecy privilege in Canada and other advanced democracies has become a prominent feature of the national security landscape post-9/11 that is consistently assailed by civil libertarians, concerned jurists and human rights activists because of the harm to individuals that can result from its use in judicial proceedings (by precluding a defendant from having the evidence against him or her tested in a full, open and adversarial hearing) and because of its negative impact on the integrity of our democratic system. ${ }^{128}$ That justice cannot be seen to be done in such proceedings goes against the longestablished principle of English law that justice should be seen to be done. ${ }^{129}$ The claimed necessity to protect state secrets from disclosure ("loose lips sink ships") has led to increased tensions with the normally recognized democratic requirements of transparency, accountability, public scrutiny and procedural fairness. ${ }^{130}$ The foregoing tensions, societal pressures and iniquitous effects of secrecy on democratic accountability and human rights beg the following question for future research: How do

125 In a 2002 speech, Federal Court Justice Huggesson captured very well the dilemma now faced by judges when dealing with state secrecy claims:

...we [the court] talked about it, we hate it. We do not like this process of having to sit alone hearing only one party and looking at the materials produced by only one party and having to try to figure out for ourselves what is wrong with the case that is being presented before use and having to try for ourselves to see how the witnesses that appear before us ought to be cross-examined. If there is one thing that I learned in my practice at the Bar, and I have managed to retain it through all these years, it is that good cross-examination requires really careful preparation and a good knowledge of your case. And by definition, judges do not do that. We do not get to prepare our cases because we do not have a case and we do not have any knowledge except what is given to us and when it is only given to us by one party we are not well suited to test the materials that are put before us. We hate hearing only one party. We hate having to decide what, if any, sensitive material can or should be conveyed to the other party. We hate, or I certainly do, I am not sure that everybody feels the same about this, sitting in a bunker, in a sealed windowless courtroom deep in the bowels of a building in Ottawa where the air is terrible, the only thing that is good is the coffee, but we hate it. I do not think it makes us do our job particularly well. We greatly miss, in short, our security blanket which is the adversary system that we were all brought up with and that, as I said at the outset, is for most of us, the real warranty that the outcome of what we do is going to be fair and just.”

Justice Huggesson, “Terrorism, Law \& Democracy: How is Canada Changing following

September 11?” (Paper delivered at the March 2002 conference on Watching the Watcher:

Democratic Oversight), quoted in ibid at 9.

126 Supra note 124.

127 Ibid at 30.

128 For a comparative analysis of the dilemmas posed by secrecy today, see David Cole, Federico Fabbrini \& Arianna Vedaschi, eds, Secrecy, National Security and the Vindication of Constitutional Law (Cheltenham, UK: Edward Elgar, 2013).

129 Robert Pearce, "Privacy, Superinjunctions and Anonymity: 'Selling My Story Will Sort My Life Out'” (2011) 23

Denning Law Journal 92 at 94.

130 Bobbio, supra note 4 at 34; Alexander, supra note 99 at 193. 
keepers of state secrets resist the temptations of telling what they know to the rest of society in which they participate?

\section{CONCLUSION}

In concluding, I would first stress that discourses can be displaced without their practices disappearing. Secrecy has been an historical invariable, but its practices have varied in forms from age to age. Secondly, law as a discourse on secrecy has been seriously downplayed. ${ }^{131}$ Here, I agree with Hunt and Wickham that "law is one of the most voluble discourses which claims not only to reveal the truth but to authorize and consecrate it. The truth of law is not to be taken for granted but seen as a problem to be investigated." 132

Thirdly, that state secrets are protected from unauthorized disclosure the way they are today did not have to come about the way it did. Subjects' ways of thinking and doing, influenced by discourse and the contingencies of history have led us to a major paradox. If I accept Foucault's notion of discourse (in the words of Hunt and Wickham: "each discourse allows certain things to be said, thought and done and impedes or prevents other things from being said, thought and done"), ${ }^{133}$ then we are in an age where the keepers of state secrets are juggling two powerful metadiscourses, or truth-claims, whose respective purposes are somewhat at odds: one of transparency and one of necessity for a modicum of state secrecy in the name of effectiveness and the personal security of subjects. With respect to the latter, I would emphasize the accelerating shift from a post-crime to a pre-crime society in the pursuit of security (with its heavy emphasis on intelligence gathering and the exchange of intelligence across national boundaries, both done with the utmost degree of secrecy ${ }^{134}$ ), the advent of the risk society, ${ }^{135}$ and a renewed emphasis on the use of "sovereign and coercive rationalities and techniques [...] within the very territory of the liberal art of government" ${ }^{136}$ (think of the current Canadian government "tough on crime” agenda). Keepers of state secrets exposed to these rationalities and with responsibilities to act according to their logics would be in a position to be convinced that the protection of state secrets is essential; not to protect state secrets would increase risks, and reduce the ability of the state to prevent crimes and use coercion efficiently.

131 This applies in a genealogical perspective. There is no dearth of contemporary legal scholarship on secrecy.

${ }^{132}$ Hunt \& Wickham, supra note 86 at 12.

133 Ibid at 8.

134 "Pre-crime $[\ldots]$ shifts the temporal perspective to anticipate and forestall that which has not yet occurred and may never do so. In a pre-crime society, there is calculation, risk and uncertainty, surveillance, precaution, prudentialism, moral hazard, prevention and, arching over all these, there is the pursuit of security." Lucia Zedner, "Pre-crime and postcriminology?” (2007) 11:2 Theoretical Criminology at 262.

135 Which "can best be expressed as a continuing concern with the minimizing of bads against goods_-and by extension the safeguarding of elite interests." George S Rigakos and Richard W Hadden, “Crime, Capitalism and the 'Risk Society': Towards the Same Olde Modernity?” (2001) 5:1 Theoretical Criminology at 73. Risk assessment techniques and tools in the area of (national) security are heavily reliant on intelligence gathering, whose sources and methods are protected from public disclosure.

136 Mitchell Dean, Governmentality: Power and Rule in Modern Society, 2d ed (Los Angeles: Sage, 2010) at 8. 